\section{$\underset{\substack{\text { hommes } \\ \text { \& migrations }}}{ }$}

\section{Hommes \& migrations}

Revue française de référence sur les dynamiques

migratoires

1295 | 2012

Algérie - France : une communauté de destin

\title{
La place
}

Film algérien de Dahmane Bouzid

\section{André Videau}

\section{Q OpenEdition \\ 1 Journals}

Édition électronique

URL : http://journals.openedition.org/hommesmigrations/1094

DOI : 10.4000/hommesmigrations.1094

ISSN : 2262-3353

Éditeur

Musée national de l'histoire de l'immigration

Édition imprimée

Date de publication : 1 janvier 2012

Pagination : 177

ISSN : 1142-852X

Référence électronique

André Videau, «La place », Hommes \& migrations [En ligne], 1295 | 2012, mis en ligne le 29 mai 2013, consulté le 22 septembre 2020. URL : http://journals.openedition.org/hommesmigrations/1094 ; DOI : https://doi.org/10.4000/hommesmigrations.1094

Ce document a été généré automatiquement le 22 septembre 2020.

Tous droits réservés 


\title{
La place
}

\author{
Film algérien de Dahmane Bouzid
}

\section{André Videau}

1 On est un peu interloqué quand on voit que La Place est fièrement présentée comme la première comédie musicale algérienne et même "maghrébine", pour faire bonne mesure. C'est vrai que les années troubles et meurtrières qui vinrent trahir les promesses de l'aube des indépendances n'étaient guère favorables à la création cinématographique. En dehors de quelques oiseaux rares (Nadir Moknèche: Viva Laldjérie, 2003, Délice Paloma, 2007 ; Tariq Teguia: Rome plutôt que vous, 2008, Inland, 2009 ; Belkacem Hadjadj: El Manara, 2004), peu de réalisateurs prenaient le relais, s'émancipaient des lourdeurs esthétiques, démocratiques et populaires formatées à l'Est. Tout le secteur donnait des signes d'épuisement. Plus de studios ni de salles de projection. Plus d'artistes ni de techniciens. Plus de crédits et, au final, plus de spectateurs. Ajoutons un climat hostile fomenté par les censures politique, religieuse, coutumière. Une attitude d'attraction/répulsion pour les valeurs occidentales aboutissant à "ce couvre-feu” dans les têtes qu'évoque le réalisateur.

2 Sans que l'Algérie ait pris la place qui lui était due dans les printemps arabes, les choses sont en train de changer.

3 Donc regardons sans sourciller cette "place" au soleil, un film tonique et imprévu. C'est un terrain resté vague entre les barres d'immeubles d'un lotissement récent et inachevé qui va servir de cadre à la comédie. Il a tout naturellement pris les fonctions sociales et ludiques d'un forum. Rendez-vous des hommes d'affaires fortuits, des matchs sans stade, du trabendo des pièces de rechange et de l'immobilier, de l'exubérance des corps et des parades amoureuses et vestimentaires, des revendications juvéniles ou féministes et, de façon plus directe, de la corruption, de l'oisiveté, du commerce des devises et des visas... De quoi indisposer tous les responsables ayant une once de pouvoir, sauf à se faire passer pour une inoffensive allégorie.

4 L'idée de la comédie musicale décalée et kitsch, ni hollywoodienne, ni bollywoodienne, mais se riant des influences dans un joyeux salmigondis, a soulevé le couvercle de la cocotte-minute sans créer de déflagration. La contagion hip-hop, les rythmes rap, 
l'énergie des jeunes interprètes amateurs ont séduit les publics des festivals (Montpellier, Madrid, Oran, Milan, Nabeul, Fameck). Parions que ce coup d'essai fera école. 